Relations industrielles

Industrial Relations

\title{
On the line: Women and Fish Plant Jobs in Atlantic Canada
}

\section{Cynthia Lamson}

Volume 41, numéro 1, 1986

URI : https://id.erudit.org/iderudit/050186ar

DOI : https://doi.org/10.7202/050186ar

Aller au sommaire du numéro

\section{Éditeur(s)}

Département des relations industrielles de l'Université Laval

\section{ISSN}

0034-379X (imprimé)

1703-8138 (numérique)

Découvrir la revue

\section{Citer cet article}

Lamson, C. (1986). On the line: Women and Fish Plant Jobs in Atlantic Canada. Relations industrielles / Industrial Relations, 41(1), 145-156.

https://doi.org/10.7202/050186ar
Résumé de l'article

On the Line : Women and Fish Plant Jobs in Atlantic Canada
Tous droits réservés (C Département des relations industrielles de l'Université Laval, 1986
Ce document est protégé par la loi sur le droit d'auteur. L’utilisation des services d'Érudit (y compris la reproduction) est assujettie à sa politique d'utilisation que vous pouvez consulter en ligne.

https://apropos.erudit.org/fr/usagers/politique-dutilisation/ 


\title{
DISCUSSION
}

\section{On the Line: Women and Fish Plant Jobs in Atlantic Canada}

\author{
Cynthia Lamson
}

The serious financial difficulties of the largest Atlantic Canadian fish processing firms have been making headlines ${ }^{1,2}$ for the past three years ${ }^{3}$. Reference is occasionally made to the number of jobs which will be lost due to fish plant closures, but rarely is there any discussion of who will be out of work. The explanation is that no one really knows much about the fish plant labour force except in vague, numerical terms, and even government statistics vary considerably about the number of fish plant workers in the Atlantic Provinces. For example, the Report of the Task Force on Atlantic Fisheries stated that, in 1980, there were some 47,000 jobs dependent on fish plant activity, but the Report conceded that the figure was probably closer to 48,000 if one included employment provided by smaller establishments. The numbers problem is compounded by the seasonal nature of many fish plant jobs, and Michael Kirby, the Task Force Chairman, could only "guesstimate» that his figures translated into 31,247 person-years of full-time employment (Task Force, 1982, p. 67).

The Task Force on Atlantic Fisheries acknowledged that fish plant employment was of significant financial importance to many households in small fishery-dependent communities. It even went to great lengths to collect data on the proportion of members in fisherman's households holding fish plant jobs. However, it failed to examine the contribution of fish plant income to non-fishing households in those same communities. Perhaps even more significantly, the Task Force Report failed to consider the ramifications of fish plant work for the household as a unit. Although it is generally

- LAMSON, Cynthia, Research Associate, Dalhousie Ocean Studies Program, Dalhousie University, Halifax, Nova Scotia.

** This research was funded by a 1982-1983 research award from the Canadian Research Institute for the Advancement of Women (CRIAW). The author is indebted to the women who participated in the study and, in particular, to Anne Bishop, Jane Burns, Serena Parsons, Elizabeth Planetta, and Lucy Porter for their able field assistance.

1 George EMERSON and Marilyn MACDONALD, «National Sea Shut-Down Leave 1800 Out of Work», Chronicle-Herald, Halifax, August 12, 1981.

2 "Third Fishing Company Goes Under», Globe and Mail, Toronto, August 17, 1983.

3 In January, 1982, Prime Minister Trudeau appointed Michael Kirby to chair a federal government Task Force on the [Canadian] Atlantic Fishery. The creation of the Task Force was a delayed response to the industry-wide crisis experienced as a consequence of declining fish prices, sluggish markets, large product inventories, escalating operating costs and skyrocketing interest rates.

Relat. Ind., vol. 41, no 1, 1986 (C) PUL ISSN 0034-379 X 
known that there are large numbers of women between the ages of 19 and 55 working in plant production lines, a breakdown by gender of the fish plant labour force is not common ${ }^{4}$. There are even less reliable data describing the circumstances of these women. Why, for example, are they working in fish plants? What employment alternatives are available? Do they perceive or report occupationally-related hazards to their health? What types of household adjustments are required as a consequence of their work ${ }^{5}$ ?

To begin to fill some of these information gaps and to provide direction for future research, a pilot study was conducted in the spring and summer months of 1983 among female fish plant workers in five Nova Scotia and Newfoundland fish processing plants ${ }^{6}$.

\section{THE STUDY}

The «trigger» behind this investigation was a submission by the Lismore (Nova Scotia) Community Concern Committee to the Task Force on Atlantic Fisheries which, in part, read:

When we read articles in the press about the seafood industry, we see several myths repeated over and over. The first is that seafood workers, since we are mostly women, are working for a second income, a little pad for the family, or a little independence for ourselves. The income is not needed in the way that men's incomes are.

The second myth is that we won't travel to find jobs. If work isn't a few miles down the road, we forget about working at all.

The third is that we are lazy, irresponsible workers who shirk, steal the meat, sabbotage the product and get out of work any way we can...7

Expressions of frustration among fish plant workers are not unusual, however, the Lismore appeal was somewhat unique because it highlighted the perception among seafood workers that the quality of their work and personal integrity are questioned by the public. In order to alter perceptions, it is first necessary to demonstrate that existing perceptions are inaccurate and cannot be substantiated. To this end, a study about female fish plant work was initiated to inquire about a broad spectrum of issues in three general data categories: personal, household and workplace. In total, fifty-

4 A 1982 report, A Study of the Potential Socioeconomic Effects on the Newfoundland Fishing Industry from Offshore Petroleum Development, prepared for the East Coast Petroleum Operators Association (EPOA), provides a breakdown of the fish plant labour force in Newfoundland by gender (see Table 30); the Annual Statistical Reviews, published by the Canadian Department of Fisheries and Oceans, do not provide similar data.

5 The need for studies of this nature was articulated by University of British Columbia Professor Patricia MARCHAK in her Keynote Address to the Newfoundland Conference on Women and the Economy, entitled, "Women in the Economy: Debates and Directions for Research'), July 28, 1982.

6 The plants were located in the communities of Hants Harbour and South Dildo, Newfoundland, and Lismore, North Sydney and Lunenburg, Nova Scotia.

7 Wilkie TAYLOR, "Fear of Unemployment Silences Workers: Brief», ChronicleHerald, Halifax, July 31, 1982. 
five women were interviewed. All were asked to complete a questionnaire comprised of 104 questions and informal interviews were conducted with 35 female fish plant workers. The study included women who worked in canning operations (lobster and crab) and groundfish processing. In two locations, women were temporarily unemployed due to recent plant closures (Lismore, Nova Scotia and South Dildo, Newfoundland). Two of the plants were large offshore fish processing facilities which meant that production operations were structured by shift work (North Sydney and Lunenburg, Nova Scotia). In terms of labour association or union affiliation, about half of the respondents were represented by the powerful Newfoundland Fishermen, Food and Allied Worker's Union (NFFAWU), and the remaining 50 percent were represented by the smaller and less-vocal Canadian Seafood and Allied Workers Union (CSAWU) which represents plant workers in Nova Scotia and New Brunswick.

\section{STUDY RESULTS}

\section{The Women and their Households}

The median age of the 55 women surveyed was $291 / 2$; the youngest respondent was 19 and the oldest was 55 . Contrary to popular perceptions about the immobility of rural women, thirteen of the sample reported having lived for short periods in other Provinces, and more than 50\% had lived in communities other than those of their current residence. Reasons given for moving included: looking for (or finding) work, and the desire to accompany family members who wanted to move. With respect to level of education attained, 22 reported a level of Grade 9 or under; 33 reported completion of high school; 6 had some vocational or business college experience, and three had taken a few university-level courses.

Sixty-seven percent of the sample reported having work experience in non-fish plant jobs, with many reporting multiple previous employment experiences. Nearly half of these respondents (19/37) had worked in the food and beverage sectors (e.g., waitress, hostess, cook or cafeteria worker). In terms of logevity with the same employer, 28 (or 50\%) had worked in the same plant for four or more years, while 15 had worked for three years; 5 had been with the same employer for one to two years, and only 7 respondents had worked in the same fish plant for less than a year.

Forty-three women stated they were presently married, 3 were divorced and 9 were single. Thirty-six support (or help support) children from 1-24 years of age still living at home. Only one woman in the entire sample reported living alone; all other households consisted of at least two, but no more than seven, persons residing on a full-time basis under the same roof.

Eight respondents indicated that they earned monies in addition to their fish plant wages; not one reported earning a second wage on a regular basis. With respect to the contribution of their earnings to total household incomes, responses ranged from $10 \%$ to $60 \%$, however, more than half indicated their contribution comprised $40 \%-60 \%$ of total household income. In dollar terms, total household incomes were reported to be in the $\$ 7,000$ 
to $\$ 18,000$ range. Twenty-nine women reported that they were primarily responsible for household bookkeeping and accounting, and 9 stated that their husbands assumed this responsibility.

When queried about membership in church, service, or social voluntary associations, only 18 women indicated they were members of some type of organized, non-work related association. However, over half replied that they attended occasional, special-purpose or «issue» meetings when events or situations were of special importance to their jobs or communities ${ }^{8}$. In terms of personal use of time and recreational opportunities, the women surveyed indicated that they divided what time was available to them between relaxing at home (reading, sewing, knitting, watching TV, etc.), and taking part in some type of social activity outside the home. On average, the women in the sample reported participating once a week in some form of social activity such as dancing, playing cards, bingo or darts, floor hockey, or baseball. Women who worked night shifts in fish plants reported lessfrequent social activity and emphasized the brevity of time to spend with children during the day before work and on Sundays.

\section{The Workplace}

Fish plant jobs are paid according to their classification: «light» or "other» labour; cutters; boiler room and refrigeration operations; and plant, ship and electrical maintenance. The majority of women surveyed (51) were classified as «light» labour - sorters, packers, trimmers - paid at rates between $\$ 6.57-\$ 6.77 / \mathrm{hr}$. (Nova Scotia) and $\$ 6.85-\$ 6.95 / \mathrm{hr}$. (Newfoundland) ${ }^{9}$. Only four women held jobs paying higher wages: a cutter, a quality control supervisor, a machine feeder and can-closing machine operator. According to the sample, no woman occupied a job in the highest paying categories which have traditionally been the exclusive domain of male fish plant workers. One woman remarked:

«Jobs not related to production work paid more and always went to male persons due to the fact that physical strength was needed beyond female capacity - company explanation!!»

The transitional category between traditionally «male» and «female» jobs appears to be the «cutter» category. Although the majority of cutters in the plants are still men, women are gradually moving into this category at the discretion of management. It is perhaps noteworthy that women in the sample, when queried about which jobs paid the most at the plant, replied that cutters were paid the best wages. Although they also indicated that men

8 For a discussion of women's activities in Newfoundland, two unpublished papers are noteworthy, see: Dona LEE DAVIS, «Social Structure, Sex Roles, and Female Associations in a Newfoundland Fishing Village", paper presented at the CESCE meetings, Banff, Alberta, February 1979; and Marilyn PORTER, «'A Tangly Bunch': The Political Culture of Outport Women in Newfoundland», September 1982, mimeo.

9 See collective agreements by and between National Sea Products Ltd. and the Canadian Seafood Workers Union, and Local 1252, Newfoundland Fishermen, Food and Allied Workers Union, 1980. 
held the maintenance, boiler, and refrigeration jobs (actually paid at the highest rates), the women apparently did not perceive that opportunities existed for them to move vertically into this traditionally male-dominated classification, so their responses reflected the highest wage level they perceived as being obtainable to them.

None of the plants surveyed have established guidelines or procedures for job-upgrading; job vacancies are posted and individuals are expected to indicate their interest in job advancement or change to their supervisors. A Canadian Seafood Workers Union executive acknowledged that workers were generally «locked in» to their classification unless: (a) the employee took the initiative to apply for another position or (b) management singled out an individual and offered him/her a more senior position ${ }^{10}$. There is, however, considerable horizontal job mobility within plant, and the majority of women with multi-year plant experience had worked at several different «light labour» jobs. In the smaller plants particularly, women workers are expected to «do whatever has to be done». In large plants, positions on packing lines are rotated on a daily basis; in plants where production bonus systems are operative, positional rotation functions to alleviate stress associated with surpassing production quotas and earning bonus wages since positions at the head of a line are advantageous in terms of access to materials.

Opinions about the utility of bonus incentive systems to increase production were mixed. Although the majority of women answered affirmatively, dissenters noted inefficiency as a consequence and several suggested what they perceived as being more effective means of controlling production:

«... they do it faster but the meat is not clean - then someone else has to re-do it.»

«not really - a foreman pushing has more effect.»

«don't know - threats are better.»

Although union labour contracts classify wage rates on the basis of job and not gender, a large number of questionnaire respondents perceived that men were paid higher wages or received preferential treatment than their female counterparts at the same job ${ }^{11}$. Typical of the comments about this perceived discrimination were:

"When men cutters are finished they can go home. Women cutters have to stay to help with other jobs like trimming and packing. Cutting is a trade, both men and women should have the same opportunities."

«... there is more work expected from the women than the men. There was a fellow there working with me - he got paid more. He had to lift boxes - but I helped him.»

10 Personal communication, Lawrence WILNEFF, President, Canadian Seafood and Allied Workers Union, September 1, 1983.

11 CONNELLY and MACDONALD also noted the prevalence of perceived discrimination between male and female in their study of rural Nova Scotia communities 1983:63. 
With respect to job satisfaction, women working in the smaller, seasonal plants were generally more positive about their jobs than their counterparts who worked in fish plants on a year-round basis. Seasonal workers cited "money", "getting out of the house», and «the opportunity to socialize" as reasons for liking their work, while year-round fish plant workers tended to perceive "money» as the primary (and sometimes single) benefit of fish plant work. One respondent articulated her perception of the non-monetary benefits of her job:

«Housework is shared. Work is cheap socializing and the money earned contributes to the family pot.»

Full-time employees working night shifts were most dissatisfied with their present jobs for family and household reasons, including: not having enough time to be with husbands and children; not being able to keep up their homes to a perceived standard of tidiness; being continuously tired and moody; no time to spend with friends or to partake in outside activities:

"When working in the plant I'm 'growly' like a bear all the time.»

«... very irregular hours making my day completely opposite from the 'normal' day. Work is not reliable - you may only work one out of six days [a plant week], therefore you really can't plan for any free time - get out of touch with friends - not much time for personal relaxation.»

«My love life is shot to hell. My housework is only half done when and if it gets done. My children are not getting complete attention. My nerves are shot. My laundry room gets so full of clothes I can hardly get in. I never see my husband - only for an hour or so when I come home from work and he is on his way out to work.

With respect to the workplace, many year-round workers cited boredom as a negative aspect to their work. In addition, a number of women were expressly critical of the long hours, irregular schedules, supervisory practices and demanding performance standards. When asked what they liked least about fish plant work, responses tended to reflect shared sentiments. For example:

«... The six-day, 48 hour-plus [plant] week and the very bad attitude of management."

«Having to put out so many boxes of fish an hour, and run for your supplies at the same time.»

«I like my job but different rules and regulations make it hard to try and stay there."

«I dislike the way they give out warning slips. They pass them out just as if someone was passing out candy.»

The principal perceived occupational hazards of fish plant work were: slippery, wet, cold and hard floors; cutting fingers with knives, or catching fingers and clothing in wringers or other production machinery. Packers and weighers cited the experience of frequent muscle pulls, back strains and aches from continuous lifting of heavy trays and boxes. A number of women working in lobster and crab operations spoke about allergies, rashes, and developing respiratory problems which they attributed to extended exposure to «sweet» odours and steam: 
«One girl's lung was affected - she needed oxygen - 'crab lung'. When I come out into the fresh air I want to vomit. $\rangle^{12}$.

The majority of workers rated plant safety and sanitation as being «fair» and «good», although many of these same respondents noted that dirty washrooms, accumulated garbage and cluttered floors were sanitary hazards, while poor ventilation, wet floors and sharp-edged machinery were safety hazards. Supervisory pressure was also perceived by a number of production workers as being counterproductive to plant safety:

«I think that the 'slip' system at the plant is poor. The workers are so scared of getting slips that they are unable to function normally - they become nervous. There are three slips issued - white, blue, pink. Each slip lasts a period of twelve months. If a person receives a pink slip you may either be fired or receive 2-days suspension. This is not a very pleasant thought to have hanging over your head. Imagine not knowing from one hour to the next about your job security. $\gg^{13}$

The most negative responses about plant safety, sanitation and management were expressed by former employees of a lobster canning factory which had been, according to company spokesmen, closed for reasons of economy. Many plant workers, however, believed that the plant was a viable operation and that poor management was the cause of the facility's eventual closure:

«Our fish plant was closed in 1982 putting 92 people or more out of work. It was caused by poor management and lack of communication with the people. I can't understand why this was allowed to happen - this plant has been in the area for 50 years or more, and everyday you see trucks going by to New Brunswick or Prince Edward Island with fish we could be doing. Instead, most of us are home with our husbands out of work, and our U.I.C. gone. We were lucky enough to get two government grants which helped some for awhile, but now it is a very sad situation in the area and it seems that nobody cares."

The fish plant workers in the sample did not seem to know very much about what happened to their product when it left the plant, and only 20 respondents gave even a tentative answer about product destination and potential markets. When asked if they could recommend their product to consumers, response was mixed, although workers in certain plants tended to have a higher degree of confidence in their product than others (for example, crab packers in Hant's Harbour, capelin packers in South Dildo, and groundfish and cooked fish packers in Lunenburg perceived their product to be high quality, good to eat, and fit to serve their own families).

12 The incidence of respiratory asthma among Gaspé fish plant workers handling shellfish was investigated from 1980 until 1982 by Québec Provincial health authorities at the request of Madelipêche and National Sea Product workers.

13 The Collective Agreement By and Between National Sea Products Ltd. (St. John's) and Local 1252, NFFAWU (80/82) specifies minor and major plant rules and penalties, as well as the warning slip system. The collective agreement between National Sea and the CSAWU does not contain similar information. 
Clearly, fish plant workers appear to be extremely conscious of quality, and those who responded to the questionnaire that their product output was of inferior quality also offered explanations:

«I would not recommend the product to the consumer. I feel that we could do a better job on the product if the girls did not have so much pressure on them to speed up.»

"As a cutter I see the fish when it comes into the plant. About $60 \%$ of the time I wouldn't eat the fish and so I wouldn't expect anyone else to.»

«... its usually not fresh enough to feed an animal.»

«Most of the fish we process ins't fit to eat. It is usually spoiled when we get it to process."

In terms of communication channels within the plant and opportunities for employees to express ideas to supervisors and management, responses tended to be plant-specific. A Lunenburg employee stated that her boss would call her at home if the work schedule changed; a North Sydney woman commented that the supervisor would yell across the floor to notify line workers about overtime work. In general, rapport with supervisors and the degree of confidence in job security appear to be key factors in determining whether workers perceived themselves at liberty to express their ideas and concerns to supervisors.

\section{Analysis}

The study findings clearly challenge the "myths» about seafood workers as articulated by the Lismore Community Concern Committee that (1) fish plant work is a secondary source of household income; (2) female fish plant workers are unreliable, or a liability because of a tendency to quit a job for minor reasons; and (3) that female workers are less mobile than men, or are less likely to seek employment opportunities if they are not locally available.

The importance of womens' wages to the household economies of Atlantic coastal communities and workforce reliability are highlighted in the study findings which indicate that, despite degrees of job dissatisfaction, the majority of female plant workers have remained in the same job for three or more years because "they need the money» above all else. Twenty-four of the respondents indicated that they travelled (by car) 20 minutes or more to their place of work, and at least 15 travelled 45 to 50 minutes to work each day. This information contradicts the third «myth» that fish plant employees work simply because convenient wage opportunities are locally available. Instead, it suggests that their wage employment is an essential component of household income. Further, the majority of women surveyed did not express an individualistic, achievementorientation towards work. Few indicated they had any long-range career aspirations. However, the majority did express a preference for obtaining a «better» job, defined as one with more security, higher wages, and hours more complementary to family life. The centrality of household welfare as opposed to individual welfare - was underscored by responses to ques- 
tions in each category. Thus, it was the household, rather than the individual, that was perceived as the central economic unit, and the importance of women's work is indicated by the estimated contribution their wages make to the total income of the household (i.e., 10\%-60\%).

Many of the women in the study indicated that they were responsible for keeping the household accounts, and that they were equal partners in making major budgetary and family decisions. None of the women in the sample intimated that they perceived themselves as being less than equal partners in their own households, but many perceived gender-dependent role and status discrepancies in the workplace.

Despite geographic, operational and organizational differences among Atlantic fish processing plants, workers in each of the five plants shared the common perception that they were fortunate to have jobs at all, given the scarcity of regionally-available employment alternatives. Women who had already lost their jobs due to plant closures, as well as those facing uncertain futures while federal fishery restructuring plans were being negotiated, were generally pessimistic about employment opportunities improving in the immediate future. Temporary, alternative job opportunities provided by government-assisted grant programs and special works' projects were most frequently-cited possibilities. A number of workers mentioned clerk/cashier, waitress and hospital jobs which occasionally became available, and two mentioned crafts as potential sources of alternative income. Note that the majority of perceived employment options are seasonal or occasional in nature, and highly dependent on government financing. These perceptions, coupled with numerous references to politician's power and the differential ability of big business to obtain grants and loans, are indicative of the pervasive sense of powerlessness to alter individual or collective economic well-being which exists in many fishery resource-dependent communities in Atlantic Canada ${ }^{14}$.

Among the occupational community of female fish plant workers, frustration and alienation is fed in part by the continuous battle to shift the burden of production costs from capital to labour. Fish processing personnel bear the costs of producing a quality fish product, yet they have limited authority to make decisions concerning production procedures. For example, fish plant workers have virtually no control over the raw material accepted for processing in the plant. Fish that has been improperly handled, or permitted to get soft prior to processing, is much more difficult to cut than fresh, firm fish. Since plant workers are paid for production based on volume rather than quality output, their earnings are tied directly to the quantity and quality of raw product delivered to them, as well as to the capacity and efficiency of the equipment they use. Fish plant workers, therefore, bear the costs of producing a quality product because careful, thorough work requires more time and reduces output volume. Although

14 Partial explanations for this pervasive sense of powerlessness are provided by, for example, Underdevelopment and Social Movements in Atlantic Canada, Robert J. BRYM and R. James SACOUMAN (eds.), Toronto, New Hogtown Press, 1979; and Ralph MATTHEWS, "Two Alternative Explanations of the Problem of Regional Dependency in Canada", Canadian Public Policy, VII, 2, 1981, pp. 268-283. 
the market place rewards fish product quality in terms of commanding higher prices, the surplus value rarely flows back to labour. Several comments by fish plant workers participating in the study reveal the kinds of pressures exerted by management to produce a quality finished product in large volume:

«Some of the fish which comes through here smells so bad it makes you sick. Some of the fish have so many worms in it you can't get them all out. But you are forced to and if any worms are found, that poor girl will get a warning slip.»

«In my opinion a fish plant is just like any other company. The companies are always there to get what they can get from the people and give as little as possible in return. I don't feel as a rule that the fish going out of the plant is as good as it should be. Today, everything is fast, get it all done in a hurry. The "Bonus System" should never have gone into the plants as the people are working too hard to put out the fish, doing it as fast as they can. To have quality and performance is impossible. To have the fish free from worms and packed clean, it has to be one or the other. People are human and not machines. The company has to have markets and make money, and the employees need to pack the fish and feel free from pressures to do their jobs and do the best they can.»

«I think the plant is like all companies - they want the fish out fast. The people are the ones to loose. They have to work so hard and fast. They can't do a good job on the fish. They want people to give them quality and performance so one is going to go down. If the fish was of good quality when they got it, they could have both.»

Union affiliation appears to be an important factor in providing fish plant workers with at least minimum degrees of job protection as well as maintaining baseline health and safety standards. With respect to job security, fish plant workers are afforded degrees of protection through union contracts, but the scope and extent of protection is highly variable, depending on a particular union's ability to negotiate conditions with fish processing firms. Although several multi-plant contracts have been negotiated in Atlantic Canada (for example, the Canadian Seafood Workers Union negotiated in 1981 on behalf of National Sea Products Ltd. employees at plants in Louisbourg, Halifax, Lockeport, Lunenburg, and North Sydney, Nova Scotia) more often contracts are negotiated on a plantby-plant basis. Plant workers who work under a common collective agreement may be disadvantaged because working conditions in each plant vary with respect to facilities, equipment, raw product, and management. For example, the Lunenburg division of National Sea Products Ltd. is considered to be the firm's gem, a world-class fish processing plant, but facilities and working conditions in National Sea plants in other locations are not as modern or congenial. Furthermore, there are important differences among union-negotiated labour contracts with respect to fish plant working conditions, as a comparison between NFFAWU and CSAWUnegotiated contracts reveals. For example, the CSAWU 5-plant agreement with National Sea Products Ltd. for Nova Scotia is silent about working conditions and safety, while the NFFAWU contract with National Sea Products Ltd. in St. John's, Newfoundlnd contains eleven clauses on safety, 
two clauses with specific stipulations regarding working conditions, and an agreement to establish an in-plant Labour Management Committee for the purpose of promoting «...work [ing] together in a harmonious spirit to solve any of the problems arising between the Management and its employees ${ }^{15}$. Maternity leaves for a period of nine months are permitted under the NFFAWU contract, but the CSAWU contract has no such provision. No fish plant in Atlantic Canada has daycare facilities available to its employees.

All fish plant workers, but women employees in particular, are relatively disadvantaged members of the working class in Canada with respect to wages, job security, working conditions and employee benefits. Much of this is related to the nature and structure of the Atlantic fishing and fish processing industry, and current industry restructuring activities pose a real threat to the number of existing fish plant jobs. A more insidious consequence of restructuring than the loss of jobs may be the price, in terms of working conditions, employees are forced to concede if jobs become more scarce. The industry-wide crisis has reduced organized labour's ability to bargain on behalf of its membership, and many fish plant workers are working under the terms of expired contracts ${ }^{16}$. Job security, once partially afforded by the seniority system, may disintegrate if plants are shut down and company operations are consolidated:

Because seniority is organized on a plant basis as opposed to an industry-wide basis, workers forced to go to another fish plant for a job (if they can get one) will start again with no seniority. Protesting fish plant workers in communities like Burin and St. Lawrence [Newfoundland] are objecting to more than a short drive down the road in their present struggle to have their plants reopened.

If and when their own plant does re-open, the seniority system may still be in danger. If the plant is opened under new management, the new company may decide that it does not want to take the union with the company. Under normal circumstances it must do so; but there is presently a case before the courts where this requirement is being contested... Even if the union ultimately wins, can those workers who had seniority and were not hired back on, afford to wait a year or two in order to get their jobs back? (Women's Unemployment Study Group, 1983, pp. 14-15).

In conclusion, fish plant workers remain among the least appreciated or understood labour group in Atlantic Canada. Their concerns about wages, job security and occupational health and safety are not high priority issues on the public agenda for several reasons, including the threat of unemployment, the general lack of political support behind organized labour in their region, and the persistence of myths about the need and nature of fish plant work.

15 See Collective Agreement By and Between National Sea and Local 1252, op. cit., p. 22.

16 Seven labour unions in the Atlantic Provinces have organized a (Unity '84» campaign to bring public attention to their dissatisfaction with fishing industry restructuring, plant closures, employee lay-offs, and failure to renegotiate expired contracts, see, Nova Scotia Worker, 1984:2. 
In terms of sheer numbers, fish plant workers represent a sizeable group, and therefore have the potential to bring about changes to improve their working conditions. However, their heretofore reticence to promote their concerns - publicly and collectively - has constrained their ability to bring about changes at three levels: through regulatory revisions requiring more stringent health and safety standards, through altering the sets of relationships between employers, and employees or through changing the public image of fish plant work from generally negative and inaccurate, to positive and sympathetic.

To date, the majority of studies about fish plant work have focused on problems of production from the perspective of improving technical efficiency, but rarely has production been examined from the perspective of employees and improvements to their work environment. Although there is some evidence to suggest that female fish plant workers may experience higher levels of stress and fatigue, more frequent bouts with insomnia, digestive problems and aches and pains than their male counterparts, there has been no concerted effort to examine what, if any, long term health problems may develop as a consequence of fish plant work (Messing and Reveret, 1983). Nor has there been any type of systematic analysis of the implications of fish plant work for individuals and families. Questions which require more thorough investigation include: changes in childbearing patterns, arrangements for child care, adjustments in the division of household duties, the long-term physical and mental effects of work-generated stress, extended exposure to cold, and so on. The fishing industry has been, for many years, the recipient of massive scientific and technological research support and funding; it is now time to consider the human dimension of the fish processing industry.

\section{REFERENCES}

CONNELLY, M. Patricia and Marilyn MACDONALD, «Women's Work: Domestic and Wage Labour in a Nova Scotia Community", Studies in Political Economy, No. 10, Winter 1983, pp. 45-72.

MESSING, Karen and Jean-Pierre REVERET, «Are Women in Female Jobs for their Health? A Study of Working Conditions and Health Effects in the FishProcessing Industry in Québec», International Journal of Health Services, Vol. 13, No. 4, 1983, pp. 635-647.

NORDCO LTD., Study of the Potential Socioeconomic Effects on the Newfoundland fishing Industry from Offshore Development, prepared for the East Coast Petroleum Operators Association, 1982.

NOVA SCOTIA FEDERATION OF LABOUR, Nova Scotia Worker, May-June 1984.

QUEBEC. DEPARTEMENT DE SANTÉ COMMUNAUTAIRE, CENTRE HOSPITALIER HÔTEL-DIEU DE GASPE, Projet Crustacés Rapport Final, 1983.

WOMEN'S UNEMPLOYMENT STUDY GROUP. 1983, «The Women Who Work in Fish Plants", in Not for Nothing: Women, Work and Unemployment in Newfoundland and Labrador (St. John's), 1983, pp. 7-16. 